\title{
PENGARUH KEPEMILIKAN ASET, KETERSEDIAAN INFRASTRUKTUR, DAN PENDIDIKAN TERHADAP PENDAPATAN DAN KESEJAHTERAAN RUMAH TANGGA MISKIN
}

\author{
Ni Putu Cahya Agung Tika Meidiana ${ }^{1}$ \\ A.A.I.N. Marhaeni ${ }^{2}$ \\ ${ }^{1,2}$ Fakultas Ekonomi dan Bisnis Universitas Udayana (Unud), Bali, Indonesia \\ E-mail: tikameidiana52@gmail.com
}

\begin{abstract}
Effect of Asset Ownership, Availability of Infrastructure, and Education on Income and Well-being of Poor Households. The purpose of this research is to know 1) the influence of asset ownership, infrastructure availability, and education on poor household income; 2) Influence of asset ownership, infrastructure availability, education, and income to poor households 'welfare; 3) indirect influence of asset ownership, availability of infrastructure, and education to prosperity through poor household income. The study uses primary and secondary data with Path analysis methods. The study took 81 samples in the East Bali development area, a sample withdrawal per district in the East Bali development area is each of 27 samples. The results concluded that asset ownership was positively influential but insignificant to revenues. The availability of infrastructure has no effect on revenue, while education is positive and significant towards revenue. This reflects that the development of human capital through education is a crucial determinant to lower the number of poor households. Variable asset ownership does not affect welfare, the availability of infrastructure positively affects the welfare, education and income positively and significantly to the welfare.
\end{abstract}

Keywords: asset ownership, infrastructure availability, education, income, welfare

\begin{abstract}
Abstrak: Pengaruh Kepemilikan Aset, Ketersediaan Infrastruktur, dan Pendidikan Terhadap Pendapatan dan Kesejahteraan Rumah Tangga Miskin. Tujuan penelitian ini untuk mengetahui 1) pengaruh kepemilikan aset, ketersediaan infrastruktur, dan pendidikan terhadap pendapatan rumah tangga miskin; 2) pengaruh kepemilikan aset, ketersediaan infrastruktur, pendidikan, dan pendapatan terhadap kesejahteraan rumah tangga miskin; 3) pengaruh tidak langsung kepemilikan aset, ketersediaan infrastruktur, dan pendidikan terhadap kesejahteraan melalui pendapatan rumah tangga miskin. Penelitian ini menggunakan data primer dan sekunder dengan metode analisis jalur (Path Analysis). Penelitian ini mengambil 81 sampel di Wilayah Pembangunan Bali Timur, penarikan sampel per Kabupaten di Wilayah Pembangunan Bali Timur adalah masing-masing 27 sampel. Hasil penelitian menyimpulkan bahwa kepemilikan aset berpengaruh positif tetapi tidak signifikan terhadap pendapatan. Ketersediaan infrastruktur tidak berpengaruh terhadap pendapatan, sedangkan pendidikan berpengaruh positif dan signifikan terhadap pendapatan. Ini mencerminkan bahwa pembangunan modal manusia (human capital) melalui pendidikan merupakan determinan penting untuk menurunkan jumlah rumah tangga miskin. Variabel kepemilikan aset tidak berpengaruh terhadap kesejahteraan, ketersediaan infrastruktur berpengaruh positif terhadap kesejahteraan, pendidikan dan pendapatan berpengaruh positif dan signifikan terhadap kesejahteraan.
\end{abstract}

Kata kunci: kepemilikan aset, ketersediaan infrastruktur, pendidikan, pendapatan, kesejahteraan 


\section{PENDAHULUAN}

Masalah utama yang dihadapi oleh Negara berkembang adalah kemiskinan (Vincent, 2009). Menurut Yusuf dan Sumner (2015) faktor utama yang meningkatkan kemiskinan seperti halnya di Indonesia adalah adanya kenaikan harga bahan bakar dan kenaikan harga bahan makanan pokok seperti beras. Fenomena kemiskinan telah berlangsung sejak lama, walaupun telah dilakukan berbagai upaya dalam menanggulanginya, namun sampai saat ini masih terdapat lebih dari 1,2 miliar penduduk dunia yang hidup dengan pendapatan kurang dari satu dolar per hari dan lebih dari 2,8 miliar penduduk dunia hanya berpenghasilan kurang dari dua dollar perharinya. Masyarakat hidup dibawah tingkat pendapatan riil minimum international (Sri budhi, 2013). Target dari pembangunan nasional adalah mengurangi tingkat kemiskinan. Kemiskinan juga sudah menjadi perhatian yang utama dalam perkembangan kebijakan sosial (Alcock, 2012). Kemiskinan bersifat multidimensional, menyangkut segi ekonomi, sosial, politik, kultural, perilaku, kepribadian, dan lain sebagainya (Bourguignon, 2003).

Wajah kemiskinan di Indonesia masih didominasi oleh kemiskinan pedesaan meskipun faktanya demikian sekitar setengah dari populasi tinggal di daerah perkotaan saat ini. Tingkat kemiskinan di daerah pedesaan selalu jauh lebih tinggi dari pada di daerah perkotaan (Suryahadi et al, 2012). Sadar akan berbagai kekurangan masa lalu, pemerintah kemudian menetapkan paradigm baru dalam strategi penanggulangan kemiskinan, yakni menggerakkan partisipasi masyarakat miskin. Masyarakat itu sendiri yang paling mengetahui masalah dan kebutuhannya, dimana masyarakat yang harus dibuat aktif dan menjadi mandiri dalam menanggulangi masalah kemiskinannya. Sebuah rumah tangga dikatakan sebagai rumah tangga miskin jika pendapatannya berada di bawah garis kemiskinan. Status social ekonomi yang rendah bagi rakyat Indonesia, yang diakibatkan dari rendahnya kualitas pendidikan sehingga tidak masuk kelapangan kerja yang menjanjikan untuk mendapatkan penghasilan dan memenuhi kebutuhan hidup (Putri, dkk. 2013). Strategi pembangunan masa lampau yang terlalu berfokus pada idustrialisasi, dalam prakteknya cenderung top down yang berpusat pada kota dan sektor industri padat modal.

Menurut Kadir (2018),
pembangunan trategi mampu menuntaskan masalah kemiskinan dan kesenjangan yang menahun, dan tidak memberikan banyak kontribusi pada peningkatan kualitas dan daya kreasi masyarakat terutama masyarakat pedesaan. Dampaknya akan membuat masyarakat semakin tergantung dengan menunggu adanya proyek dari pemerintah, maka dari itu, upaya penanggulangan kemiskinan seharusnya dilaksanakan secara menyeluruh (Nasir, dkk. 2008). Salah satu tujuan pembangunan nasional lainnya adalah meningkatkan kinerja perekonomian agar mampu menciptakan lapangan kerja dan menata kehidupan yang layak bagi seluruh rakyat yang pada gilirannya akan mewujudkan kesejahteraan penduduk. Kesejahteraan memiliki banyak dimensi, yakni dapat dilihat dari dimensi materi dan dimensi non materi. Dari sisi materi dapat diukur dengan pendekatan pendapatan dan konsumsi (Hukom, 2014). Indikator utama keberhasilan pembangunan nasional salah satunya adalah laju penurunan jumlah penduduk miskin (Yanthi, 2015).

Penanggulangan kemiskinan harus dilakukan secara terpadu, bertahap, terukur, sinergis, terarah, dan terencana yang dilandasi oleh keterlibatan stake holders untuk mewujudkan pemenuhan hak-hak dasar penduduk miskin, seperti: hak atas pangan, hak atas layanan kesehatan, pendidikan, lapangan pekerjaan dan berusaha, hak untuk perumahan yang layak, hak atas air bersih, dan hak-hak lainnya (Verner, 2006). Bila persoalannya adalah ketidak berdayaan atau ketidak mampuan, maka kebijakannya adalah bagaimana memperdayakan masyarakat miskin, agar hasil pemberdayaan bisa berkelanjutan, pilihannya adalah harus melibatkan partisipasi aktif masyarakat 
miskin dalam menanggulangi masalahnya sendiri. Jika dilihat berdasarkan pendekatan ekonomi regional, maka peran kelas menengah merupakan modal sosial yang sangat penting dalam pelaksanaan perencanaan penurunan kemiskinan di daerah, khususnya perdesaan sebagai nadi perekonomian Indonesia (Anne Booth, 2000).

Pertumbuhan ekonomi memang penting, strategi penanggulangan kemiskinan yang lebih lengkap harus mengambil faktor yang relevan, dalam konteks desentralisasi, analisis subnasional dapat menjadi pendekatan instruktif untuk memeriksa pemerintahan lokal dalam kaitannya dengan pertumbuhan dan pengentasan kemiskinan (Balisacan,2003). Kemiskinan dapat menghambat pencapaian demokrasi, persatuan dan keadilan, serta tujuan pembangunan. Pendapatan memiliki hal yang positif dan signifikan dengan kemiskinan dan pertumbuhan ekonomi (Abebe, 2014). Salah satu bentuk penanggulangan kemiskinan yang cukup efektif adalah pembangunan infrastruktur. Infrastruktur merupakan salah satu hal penting yang harus diperhatikan dalam pelaksaan pembangunan khususnya untuk penanggulangan kemiskinan. Beberapa infrastruktur dasar yang penting adalah keadaan jalan, akses sambungan listrik, dan bangunan sekolah. Jalan merupakan infrastruktur penting dalam memudahkan mobilitas manusia dan barang. Akses sambungan listrik juga menjadi hal yang penting karena berdampak pada kegiatan sosial dan ekonomi. Bangunan sekolah merupakan infrastruktur penting dan sudah menjadi kebutuhan dasar bagi suatu daerah. Membangun suatu daerah memerlukan manusia-manusia yang handal dan hal itu hanya dapat diperoleh melalui penguasaan terhadap ilmu pengetahuan.

Masalah kemiskinan juga tidak terlepas dari pembangunan (Tisnawati, 2016). Kesejahteraan masyarakat merupakan tujuan dari pembangunan. Kesejahteraan masyarakat dapat dilihat dari meningkatnya pertumbuhan ekonomi dan meratanya distribusi pendapatan. Walaupun kesejahteraan masyarakat Provinsi Bali meningkat setiap tahunnya, namun peningkatannya cenderung rendah dan masih terjadinya disparitas pendapatan antar daerah (Yasa Artana, 2015). Sektor pariwisata merupakan tulang punggung pertumbuhan ekonomi di Bali, meskipun Bali dikenal sebagai daerah pariwisata, namun dari 9 wilayah Kabupaten dan Kota hanya beberapa daerah saja yang menikmati hasil dari pariwisata di Bali. Kecenderungan nilai PDRB tertinggi masih didominasi oleh Kabupaten Badung dan nilai terendah didominasi oleh Kabupaten Bangli.

Provinsi Bali sebagai salah satu wilayah dengan sebaran yang cukup tinggi juga mengalami ketidakmerataan dalam percepatan pembangunan antar wilayahnya. Perbedaan karakteristik baik dari letak geografis dan potensi sumber daya yang berbeda di masing-masing wilayahnya mempunyai pengaruh kuat pada terciptanya pola pembangunan ekonomi menjadi tidak seragam dan menimbulkan kemampuan tumbuh yang berbeda. Kemampuan tumbuh yang berbeda ini menimbulkan terjadinya ketimpangan baik didalam pembangunan maupun hasil yang didapatkan. Ketimpangan sebuah pembangunan tersebut didalamnya juga terdapat ketimpangan pendapatan.

Pergeseran pola pengeluaran untuk konsumsi rumah tangga dari makanan ke non makanan dapat dijadikan indikator peningkatan kesejahteraan masyarakat, dengan anggapan bahwa setelah kebutuhan makanan terpenuhi, kelebihan pendapatan akan digunakan bukan untuk makanan, oleh karena motif konsumsi atau pola konsumsi suatu kelompok masyarakat sangat di tentukan oleh pendapatan, atau secara umum dapat dikatakan tingkat pendapatan yang berbeda-beda menyebabkan keanekaragaman taraf konsumsi suatu masyarakat atau individu. Peran pemerintah sebagai mobilisator pembangunan sangat strategis dalam mendukung peningkatan kesejahteraan masyarakat serta pertumbuhan ekonomi negaranya (Purwanto, 2018).

Masyarakat miskin umumnya lemah dalam kemampuan berusaha, dan mempunyai akses yang terbatas terhadap kegiatan social ekonomi, pendidikan, maupun kesehatan. Pola konsumsi sering digunakan sebagai 
Tabel 1.

Jumlah Penduduk Miskin Menurut Kabupaten/Kota di Provinsi Bali Tahun 2015-2017 (Ribu Jiwa)

\begin{tabular}{lccccccc}
\hline No & Kabupaten/Kota & \multicolumn{2}{c}{2015} & \multicolumn{2}{c}{$\mathbf{2 0 1 6}$} & \multicolumn{2}{c}{$\mathbf{2 0 1 7}$} \\
& & Jumlah & \% & Jumlah & \% & Jumlah & \% \\
\hline 1 & Jembrana & 15.83 & 5.84 & 14.53 & 5.33 & 14.78 & 5.38 \\
2 & Tabanan & 24.05 & 5.52 & 21.9 & 5 & 21.66 & 4.92 \\
3 & Badung & 14.4 & 2.33 & 12.91 & 2.06 & 13.16 & 2.06 \\
4 & Gianyar & 28.89 & 4.61 & 22.13 & 4.44 & 22.42 & 4.46 \\
5 & Klungkung & 12.11 & 6.91 & 11.21 & 6.35 & 11.15 & 6.29 \\
6 & Bangli & 12.74 & 5.73 & 11.66 & 5.22 & 11.76 & 5.23 \\
7 & Karangasem & 30.33 & 7.44 & 27.12 & 6.61 & 27.02 & 6.55 \\
8 & Buleleng & 43.43 & 6.74 & 37.55 & 5.79 & 37.48 & 5.74 \\
9 & Denpasar & 20.94 & 2.39 & 19.17 & 2.15 & 20.7 & 2.27 \\
\hline & Provinsi Bali & 202.72 & 4.74 & 178.18 & 4,25 & 180.13 & 4.25 \\
\hline
\end{tabular}

Sumber: BPS Provinsi Bali, 2018

salah satu indikator untuk mengukur tingkat kesejahteraan. Tingkat kesejahteraan suatum asyarakat dapat pula dikatakan membaik apabila pendapatan meningkat dan sebagian pendapatan tersebut digunakan untuk mengkonsumsi non makanan, begitupun sebaliknya. Provinsi Bali merupakan salah satu wilayah yang perkembangan perekonomiannya sangat pesat, namun ditengah pesatnya perkembangan perekonomian yang terjadi, jumlah penduduk miskin dan ketimpangan pendapatan antar wilayah masih menjadi perhatian yang tinggi.

Kondisi ketimpangan yang dialami oleh daerah-daerah yang berada di Provisi Bali terjadi akibat pembangunan Pariwisata di Wilayah Bali Utara, Barat, dan Timur yang kondisinya relatifertinggal, dibandingkan dengan Bali Selatan, sementara daerah lain seperti Karangasem, Bangli, dan Klungkung relative kurang mendapat perhatian. Masih terpusatnya kegiatan pariwisata di wilayah Bali Selatan menyebabkan pemanfaatan potensi wisata di kalangan pengusaha juga tidak merata. Selain itu sebagian besar wisatawan di Bali berkunjung di tiga destinasi utama yaitu Kabupaten Badung dengan wisata andalan Kuta dan Jimbaran. Kabupaten Gianyar dengan wisata andalan pusat perkampungan seniman Ubud dan sekitarnya serta wilayah Kota Denpasar sebagai pusat kegiatan ekonomi di Bali.

Kondisi tersebut mengakibatkan terjadinya ketimpangan dalam distribusi pendapatan antardaerahyang berada di Provinsi Bali. Ini terjadi disebabkan oleh perbedaan kemampuan daerah mengembangkan potensi yang dimiliki oleh masing-masing daerah. Disamping adanya perbedaan terkait kondisi alam dan kualitas SDM, kebijakan Pemerintah Daerah juga sedikit banyak berkontribusi dalam mengurangi ketimpangan pendapatan yang terjadi. Permasalahan kemiskinan juga masih menjadi pokok persoalan yang harus mendapatkan perhatian lebih. Pada kondisi saat ini, tingkat kemiskinan bukan hanya dipandang dari sudut yang berbeda-beda dan tergantung pandangan yang digunakan maka batasankemiskinanjuga telahbergeser. Dengan menggunakan batasan kualitas dan material, kemiskinan diartikan ketidakmampuan untuk meraih standar hidup minimal.

Dalam arti yang luas kemiskinan merupakan ketidak mampuan ekonomi tidak sebatas pada belum dapat memenuhi kebutuhan dasar namun juga secara umum belum dapat memenuhi kebutuhan sandang, pangan dan papan (Alit dan Sudiana, 2013). Kondisi kemiskinan masing-masing kabupaten/ kota yang ada di Provinsi Bali juga sangat dipengaruhi oleh kemajuan pembangunan di masing-masing wilayah kabupaten/kota 
Tabel 2.

Jumlah Rumah Tangga Miskin Menurut Kemiskinan di Provinsi Bali

Tahun 2017 (KK)

\begin{tabular}{cccccc}
\hline & & \multicolumn{4}{c}{ Jumlah RTS } \\
No. & Kabupaten/ kota & Sangat Miskin & Miskin & Hampir Miskin & Total \\
\hline 1 & Jembrana & 7.446 & 7.928 & 1.620 & 16.994 \\
2 & Tabanan & 6.844 & 9.261 & 9.337 & 25.442 \\
3 & Badung & 5.190 & 2.053 & 1.661 & 8.904 \\
4 & Gianyar & 641 & 3.200 & 6.663 & 10.504 \\
5 & Klungkung & 2.649 & 3.007 & 4.475 & 10.131 \\
6 & Bangli & 883 & 3.999 & 8.314 & 13.196 \\
7 & Karangasem & 6.892 & 10.991 & 16.715 & 34.598 \\
8 & Buleleng & 11.014 & 17.445 & 16.343 & 44.802 \\
9 & Denpasar & 1.661 & 934 & 1.083 & 3.678 \\
& Jumlah & $\mathbf{4 3 . 2 2 0}$ & $\mathbf{5 8 . 8 1 8}$ & $\mathbf{6 6 . 2 1 1}$ & $\mathbf{1 6 8 . 2 4 9}$ \\
\hline
\end{tabular}

Sumber: TNP2K (Tim Nasional PercepatanPenanggulanganKemiskinan), 2018

yang sangat ditentutkan oleh sumber-sumber dan potensi ekonomi yang dimiliki oleh masing-masing wilayah. Kabupaten/kota kaya akan sumber atau potensial ekonomi akan memiliki peluang berkembang lebih cepat dari kabupaten/kota lainnya yang tergolong daerah miskin di Provinsi Bali. Kabupaten Badung yang memiliki potensi besar dalam pengembangan kegiatan pariwisata, Kabupaten Gianyar yang memiliki potensi dalam kegiatan industry kecil dan Kabupaten Tabanan di sector pertanian. Sementara itu, kabupaten Karangasem, Buleleng, dan Kabupaten Bangli memiliki sumber atau potensi ekonomi yang relatif terbatas yang mengakibatkan terhambatnya pertumbuhan ekonomi.

Dari Tabel 1 dapat dilihat bahwa kemiskinan masih menjadi masalah di Kabupaten yang ada di Provinsi Bali. Bali yang dikenal sebagai daerah wisata yang maju seakan tidak pernah tersentuh oleh masalah kemiskinan. Namunironisnya, dibalikpesatnya industry pariwisata yang ada di pulau dewata itu, masih terdapat daerah yang mayoritas warganya miskin. Kabupaten Klungkung sebagai salah satu Kabupaten yang terletak di sebelah timur Provinsi Bali, merupakan kabupaten terkecil dari 9 kabupaten dan kota yang berada di Provinsi Bali. Pada tahun 20152017, Kabupaten Klungkung memiliki jumlah penduduk miskin paling rendah dibandingkan dengan kabupaten lain yang berada di Provinsi Bali. Bila dilihat sebaran penduduk miskin per kecataman, Kecamatan Nusa Penida merupakan penyumbang hampir sebagian penduduk miskin di Kabupaten Klungkung. Hal ini terkait dengan kondisi geografis Kecamatan Nusa Penida yang identik dengan kegersangan dan daerah yang tandus, wilayah dengan kelerengan tinggi.

Kabupaten Bangli yang juga terletak di sebelah Timur Provinsi Bali merupakan satusatunya dari Sembilan Kabupaten dan Kota di Bali yang tidak memiliki wilayah pantai/laut. Kabupaten Bangli memiliki penduduk miskin terendah setelah Kabupaten Klungkung, meskipun begitu angka kemiskinan di Kabupaten Bangli terbilang masih tinggi. Berbagai factor menjadi pemicu utama kemiskinan, seperti kurangnya infrastruktur dan ketersediaan air bersih. Berdasarkan data di Dinas Sosial Kabupaten Bangli dalam tiga tahun terakhir (2015-2017) Pemkab berhasil menurunkan kemiskinan hingga 18,6 persen. Untuk menurunkan angka kemiskinan, berbagai upaya telah dilakukan Pemkab Bangli. Program yang telah digulirkan seperti bedah rumah termasuk pemberian jaminan sosial.

Daerah yang memiliki penduduk miskin di wilayah Bali Timur salah satunya 
adalah Kabupaten Karangasem, merupakan Kabupaten yang memiliki jumlah penduduk miskin tertinggi setelah Kabupaten Buleleng. Kondisi alam yang kering, serta pemberdayaan masyarakat setempat yang kurang jelas kelihatannya telah membuat masyarakat setempat mewariskan kemiskinan secara turun temurun. Hasil obeservasi menunjukkan bahwa sebagian besar para pengemis di jalanan atau yang datang kerumah-rumah penduduk di Bali terutama di Kota Denpasar atau Kabupaten Badung berasal daridesa-desa miskin di Kabupaten Karangasem.

Berdasarkan Tabel 2 Kabupaten Karangasem memiliki rumah tangga hampir miskin tertinggi pada tahun 2017 di Provinsi Bali sebanyak 16.715 KK. Faktor dominan yang menyebabkan sebuah rumah tangga dikatakan miskin adal ah rendahnya tingkat pendidikan yang dimiliki dan pendapatan yang dihasilkan oleh kepala rumah tangga. Secara Geografis Kabupaten Karangasem terletak di ujung timur pulau Bali berdampingan dengan Kabupaten Klungkung dan Bangli. Kondisi alamnya memiliki tofografi yang sangat variatif serta tandus akibat dari letusan gunung Agung yang terjadi pada tahun 1963. Kemiskinan di Kabupaten Karangasem ini tidak hanya disebabkan oleh factor alam akan tetapi juga disebabkan oleh faktor sikap mental dan budaya.

Dengan mempertimbangkan profil kemiskinan, rumah tangga miskin cenderung mempunyai kepemilikan aset yang relative sempit dan pendapatan yang rendah. Dengan faktor-faktor tersebut kegiatan yang dilakukan relative kecil dengan cara yang sederhana, agar seseorang dapat hidup layak pemenuhan akan kebutuhan makanan saja tidak cukup, oleh karena itu perlu dipenuhi kebutuhan dasar selain makanan, seperti perumahan, pendidikan, kesehatan, pakaian, dll. Kepemilikan aset seperti lahan akan menjadi faktor yang penting mengingat dengan tersedianya lahan produktif, rumah tangga dengan lapangan usaha pertanian akan dapat menghasilkan pendapatan yang lebih baik. Kepemilikan modal fisik ini dan kemampuan memperoleh pendapatan sebagai tenaga kerja akan menjadi modal utama untuk menghasilkan pendapatan keluarga. Anggota rumah tangga yang tidak memiliki modal fisik terpaksa menerima pekerjaan dengan bayaran yang rendah dan tidak mempunyai alternatif lain untuk berusaha sendiri.

Pendapatan dan kepemilikan aset merupakan faktor internal yang mempengaruhi tingkat kesejahteraan. Hal ini menunjukkan bahwa pendapatan merupakan faktor penting dalam meningkatkan kesejahteraan keluarga. Keluarga yang memiliki pendapatan yang tinggi memiliki peluang yang besar untuk sejahtera dibandingkan keluarga dengan pendapatan yang rendah. Pendapatan akan menentukan daya beli terhadap pangan dan fasilitas lainnya seperti pendidikan, kesehatan, perumahan, dll. Selain itu, keluarga yang memiliki aset lebih sejahtera dibandingkan keluarga yang tidak memiliki aset. Menurut Bryant (1990) bahwa aset merupakan sumber daya atau kekayaan yang dimiliki oleh keluarga. Aset akan berpengaruh sebagai alat pemuas kebutuhan. Oleh karena itu keluarga yang memiliki aset lebih banyak cenderung lebih sejahtera jika disbandingkan dengan keluarga yang memiliki aset terbatas (Iskandar, 2007)

Menurut Fedderke dan Bogetic (2000), ketersediaan infrastruktur juga sangat berpengaruh dalam menunjang kegiatan ekonomi, seperti peningkatan produktivitas tenaga kerja pada sektor manufaktur, sehingga kenaikan produktivitas tenaga kerjaakan meningkatkan pendapatan perkapita dari masyarakat miskin. Ketersediaan infrastruktur juga berpengaruh terhadap peningkatan akses masyarakat terhadap sumberdaya sehingga meningkatkan produktivitasnya sehingga pada gilirannya akan mendorong pertumbuhan ekonomi dan dapat mengurangi tingkat kemiskinan. Semakin besar investasi yang diberikan dampak ekonomi yang timbul akan meningkat dengan rata-rata yang semakinmengecil, karena sifat dari infrastruktur lebih kepada mendorong ratarata untuk daerah yang masih belum maju secara ekonomi maupun fasilitas untuk daerah yang telah maju (Pratomo, 2017). 
Kesejahteraan sosial merupakan suatu keadaan terpenuhinya kebutuhan hidup yang layak bagi masyarakat, sehingga mampu mengembangkan diri dan dapat melaksanakan fungsi sosialnya yang dapat dilakukan pemerintah, pemerintah daerah dan masyarakat dalam bentuk pelayanan sosial yang meliputi rehabilitasi sosial, jaminan sosial, pemberdayaan sosial, dan perlindungan sosial (UU No 11Tahun 2009 pasal 1 dan 2). Kesejahteraan merupakan suatu hal yang bersifat subjektif, sehingga setiap keluarga atau individu di dalamnya yang memiliki pedoman, tujuan, dan cara hidup yang berbeda akan memberikan nilai yang berbeda tentang faktor-faktor yang menentukan tingkat kesejahteraan (BKKBN 1992).

Pendapatan merupakan salah satu indikator untuk mengukur kesejahteraan seseorang atau masyarakat, sehingga pendapatan mencerminkan suatu sifat keterbatasan sumber daya keluarga atau pendapatan yang tersedia akan mempengaruhi adanya prioritas alokasi pengeluaran keluarga. Keluarga yang berpenghasilan rendah, sebagian besar pendapatannya digunakan untuk mencukupi kebutuhan pangan, sehingga persentase pengeluaran untuk pangan akan relatif besar. Peningkatan pendapatan berpengaruh besar terhadap usaha yang dijalankan oleh sebuah rumah tangga, karena pendapatan digunakan dalam kegiatankegiatan lainnya yang bersifat produktif demi kesejahteraan rumah tanga miskin (Putrayasa, 2018). Sebuah rumah tangga diidentifikasi sebagai miskin kronis jika pendapatan berada di bawah garis kemiskinan (Radhakrishna, 2007).

Memberantas kemiskinan dan meningkatkan pendidikan tidak dapat dipisahkan (Capra, 2009). Akan tetapi karena kebutuhan pangan relative terbatas, maka mulai pada tingkat pendapatan tertentu pertambahan pendapatan akan dialokasikan lebih banyak untuk memenuhi kebutuhan non pangan, sehingga pada kondisi tersebut persentase pengeluaran untuk pangan akan menurun. Peningkatan pendapatan menyebabkan timbulnya kebutuhan- kebutuhan lain selain pangan, sementara pengeluaran untuk memenuhi kebutuhan pangan dalam peningkatannya tidak sebesar pengeluaran non pangan (Fatimah,1995). Tingkat pendapatan yang berbeda akan menyebabkan alokasi pengeluaran yang berbeda, karena tingkat pengeluaran merupakan fungsi dari total pendapatan. Pada golongan berpendapatan rendah, persentase pengeluaran untuk pangan lebih besar dibandingkan pengeluaran lainnya, sedangkan pada golongan berpendapatan tinggi, persentase pengeluaran pangan lebih kecil dibandingkan dengan pengeluaran lainnya. Pada rumah tangga dengan pendapatan rendah, 60 - 80 persen dari pendapatannya dibelanjakan untuk makanan (Kembar, 2013).

Elastisitas pendapatan untuk makanan yang digambarkan dari persentase perubahan kebutuhan akan makanan untuk tiap 1 persen perubahan pendapatan, lebih besar pada rumah tangga yang miskin dibandingkan pada rumah tangga kaya (Soekirman, 2000). Untuk komoditas pangan, peningkatan pendapatan tidak diikuti dengan peningkatan permintaan yang progresif. Hal ini sesuai dengan Hukum Engel, yang menyatakan bahwa semakin rendah pendapatan keluarga, maka semakin besar proporsi dari pendapatan tersebut yang dibelanjakan untuk makanan. (Sinaga dan Nyak Ilham, 2002).

\section{Konsep Kesejahteraan}

Kesejahteraan sosial merupakan suatu keadaan terpenuhinya kebutuhan hidup yang layak bagi masyarakat, sehingga mampu mengembangkan diri dan dapat melaksanakan fungsi sosialnya yang dapat dilakukan pemerintah, pemerintah daerah dan masyarakat dalam bentuk pelayanan sosial yang meliputi rehabilitasi sosial, jaminan sosial, pemberdayaan sosial, dan perlindungan sosial (UU No 11 Tahun 2009 pasal 1 dan 2). Kesejahteraan merupakan suatu hal yang bersifat subjektif, sehingga setiapkeluarga atau individu di dalamnya yang memiliki pedoman, tujuan, dan carahidup yang berbeda akan memberikan nilai yang berbeda tentang faktorfaktor yang menentukan tingkat kesejahteraan (BKKBN 1992). Untuk mengukur efek dari kesejahteraan dan kerentanan relatif pada 
aspek kesejahteraan yaitu dengan menentukan material termasuk makanan dan tempat tinggal, hingga awal perkembangan masa kanak-kanak, paparan faktor risiko sosial, cedera dan kekerasan, stres dan determinan psiko-sosial kesehatan lainnya (Craig et al, 2003). Kesejahteraan menurut Badan Pusat Statistik (2007), adalah suatu kondisi dimana seluruh kebutuhan jasmani dan rohani dari rumah tangga tersebut dapat dipenuhi sesuai dengan tingkat hidup. Status kesejahteraan dapat diukur berdasarkan proporsi pengeluaran rumah tangga (Bappenas, 2000).

\section{Konsep Pendapatan}

Pendapatan merupakan salah satu indikator untuk mengukur kesejahteraan seseorang atau masyarakat, sehingga pendapatan mencerminkan suatu sifat keterbatasan sumberdaya keluarga atau pendapatan yang tersedia akan mempengaruhi adanya prioritas alokasi pengeluaran keluarga. Keluarga yang berpenghasilan rendah, sebagian besar pendapatannya digunakan untuk mencukupi kebutuhan pangan, sehingga persentase pengeluaran untuk pangan akan relatif besar. Peningkatan pendapatan berpengaruh besar terhadap usaha yang dijalankan oleh sebuah rumah tangga, karena pendapatan digunakan dalam kegiatankegiatan lainnya yang bersifat produktif demi kesejahteraan rumah tanga miskin (Putrayasa, 2018). Sebuah rumah tangga diidentifikasi sebagai miskin kronis jika pendapatan berada di bawah garis kemiskinan (Radhakrishna, 2007).

\section{Konsep Kemiskinan}

Kemiskinan secara umum dapat diartikan sebagai kondisi individu penduduk atau keluarga yang tidak mampu memenuhi kebutuhan hidup dasarnya secara layak. Pengertian kemiskinan adalah ketidaksamaan kesempatan untuk memformulasikan kekuasaan social berupa asset, sumber keuangan, organisasi social politik, jaringan social, barang atau jasa, pengetahuan dan ketrampilan, serta informasi. BAPPENAS (Badan Perencanaan dan Pembangunan Nasional) mendefinisikan kemiskinan sebagai situasi serba kekurangan yang terjadi bukan karena kehendak si miskin, melainkan karena keadaan yang tidak dapat dihindari dengan kekuatan yang ada padanya. Kemiskinan ini ditandai oleh sikap dan tingkah laku yang menerima keadaan yang seakan-akan tidak dapat diubah yang tercermin di dalam lemahnya kemauan tetap untuk maju, rendahnya kualitas sumber daya manusia, lemahnya nilai tukar hasil produksi, rendahnya produktifitas, terbatasnya modal yang dimiliki berpartisipasi dalam pembangunan. Menurut Badan Pusat Statistik (2012), yang dikategorikan sebagai penduduk miskin adalah penduduk yang tidak mampu memenuhi kebutuhan dasar minimum. Nilai garis kemiskinan yang digunakan mengacu pada kebutuhan minimum 2.100 kalori per kapita per hari ditambah dengan kebutuhan minimum nonmakanan yang merupakan kebutuhan dasar seseorang yang meliputi kebutuhan dasar untuk papan, sandang, sekolah, transportasi serta kebutuhan rumah tangga dan individu yang mendasar lainnya.Kemiskinan memberi gambaran situasi serba kekurangan seperti terbatasnya modal yang dimiliki, rendahnya pengetahuan dan keterampilan, rendahnya produktivitas, rendahnya pendapatan, lemahnya nilai tukar hasil produksi orang miskin dan terbatasnya kesempatan berperan serta dalam pembangunan. Ketidakberdayaan penduduk miskin, menurut Mubyarto (1998), disebabkan karena mereka tidak memiliki aset sebagai sumber pendapatan dan juga karena struktur sosial ekonomi tidak membuka peluang orang miskin ke luar dari lingkungan kemiskinan yang tak berujung pangkal.

\section{Konsep Kepemilikan Asset}

Aset adalah sumber daya ekonomi yang dikuasai dan atau dimiliki oleh Peremerintah sebagai akibat dari peristiwa masa lalu dan dari mana manfaat ekonomi dan atau sosial di masa depan diharapkan dapat diperoleh, baik oleh pemerintah maupun masyarakat, serta dapat diukur dalam satuang uang, termasuk sumber daya non keuangan yang diperlukan untuk penyediaan jasa bagi masyarakat umum dan sumber-sumber daya yang dipelihara karena alasan sejarah dan budaya (Seiler, 2001). Aset dapat dikelompokkan berdasarkan 
sifat dan jenisnya sebagai berikut.

1) Aset tak berwujud adalah aset non keuangan yang dapat di identifikasi dan tidak mempunyai wujud fisik serta dimiliki untuk digunakan dalam menghasilkan barang atau jasa digunakan untuk tujuan lainnya, termasuk hak atas kekayaan intelektual.

2) Aset tetap adalah aset berwujud yang mempunyai masa manfaat atau dimanfaatkan.

3) Aset lancer adalah aset yang diharapkan untuk segera direalisasikan, dipakai, atau dimiliki untuk dijual yang mencakup barang atau perlengkapan yang dibeli dan disimpan untuk digunakan, misalnya perhiasan.

4) Aset non lancer mencakup aset yang bersifat jangka panjang dan aset tak berwujud yang digunakan secara langsung atau tidak langsung atau yang digunakan. Aset nonlancar diklasifikasikan menjadi investasi jangka panjang seperti tanah.

5) Aset diakui pada saat potensi manfaat ekonomi masa depan mempunyai nilai atau biaya yang dapat diukur dengan andal (Lauren et al, 2012). Aset diakui pada saat diterima atau kepemilikannya dan atau kepenguasaannya berpindah. Kepemilikan aset dalam hal ini meliputi aset yang dimiliki oleh rumah tangga miskin seperti lahan pertanian, rumah, dan kendaraan.

\section{Konsep Infrastruktur}

Sampai saat ini belum ada kesepakatan mengenai definisi infrastruktur. Namun secara bahasa, dalam kamus besar bahasa indonesia infrastruktur dapat diartikan sebagai sarana dan prasarana umum. Sarana secara umum diketahui sabagai fasilitas publik seperti rumah sakit,jalan,jembatan, sanitasi, telpondsb.Lebih jauh lagi, dalam ilmu ekonomi infrastruktur merupakan wujud dari public capital (modal publik) yang dibentuk dari investasi yang dilakukan pemerintah. Infrastruktur dalam penelitian ini meliputi jalan, jembatan, dan sistem saluran pembuangan (Mankiw, 2003:38). Infrastruktur sebagai basic essential service dalam proses pembangunan. Definisi lainnya mengenai infrastruktur, yaitu bahwa infrastruktur mengacu pada fasilitas kapital fisik dan termasuk pula kerangka kerja organisasional, pengetahuan dan teknologi yang penting untuk organisasi masyarakat dan pembangunan ekonomi mereka. Infrastruktur meliputi undang- undang, sistem pendidikan dan kesehatan publik, sistem distribusi dan perawatan air, pengumpulan sampah dan limbah, pengolahan dan pembuangannya, sistem keselamatan publik, seperti pemadam kebakaran dan keamanan, sistem komunikasi, sistem transportasi dan utilitas publik. Selanjutnya, infrastruktur dapat dibedakan menjadi 2 kelompok yaitu infrastruktur berdasarkan fungsi dan peruntukkannya. Infrastruktur dibedakan menjadi infrastruktur ekonomi dan sosial. Infrastruktur ekonomi memegang peranan penting dalam mendorong kinerja pertumbuhan ekonomi di berbagai negara. Infrastruktur ekonomi diantaranya utilitas publik seperti tenaga listrik, telekomunikasi, suplai air bersih, sanitasi dan saluran pembuangan dan gas. Kemudian juga termasuk pula pekerjaan umum, seperti jalan, kanal, bendungan, irigasi dan drainase serta proyek transportasi seperti jalar kereta api, angkutan kota, waterway, dan bandara. Sedangkan infrastruktur sosial dapat dibedakan menjadi infrastruktur pendidikan dan kesehatan.

\section{TUJUAN PENELITIAN}

Tujuan dalam penelitian ini yaitu sebagai berikut.

1) Untuk menganalisis pengaruh kepemilikan aset, ketersediaan infrastruktur, dan pendidikan terhadap pendapatan rumah tangga miskin di Wilayah Pembangunan Bali Timur.

2) Untuk menganalisis pengaruh kepemilikan aset, ketersediaan infrastruktur, pendidikan, dan pendapatan terhadap kesejahteraan rumah tangga miskin di Wilayah Pembangunan Bali Timur.

3) Untuk menganalisis pengaruh tidak langsung kepemilikan aset, ketersediaan infrastruktur, dan pendidikan terhadap kesejahteraan melalui pendapatan rumah tangga miskin di Wilayah Pembangunan Bali Timur.

\section{METODE PENELITIAN}

Penelitian ini dilakukan di Wilayah 
Tabel 3.

Hasil Uji ValiditasInstrumen

\begin{tabular}{lllll}
\hline Variabel & Indikator & Koefisien Korelasi & Signifikansi Pernyataan & Keterangan \\
\hline \multirow{4}{*}{ Ketersediaan Infrastruktur } & $\mathrm{X} 2.1$ & 0,925 & 0,000 & Valid \\
(X2) & $\mathrm{X} 2.2$ & 0,885 & 0,000 & Valid \\
& $\mathrm{X} 2.4$ & 0,817 & 0,000 & Valid \\
& $\mathrm{X} 2.5$ & 0,921 & 0,000 & Valid \\
Kesejahteraan (Y2) & $\mathrm{Y} 2.1$ & 0,920 & 0,000 & Valid \\
& $\mathrm{Y} 2.2$ & 0,400 & 0,000 & Valid \\
& & 0,000 & Valid \\
\hline
\end{tabular}

Tabel 4.

Hasil Uji KMO

\begin{tabular}{llll}
\hline No & Faktor & KMO & Sig Chi-square \\
\hline 1 & KetersediaanInfrastruktur & 0,887 & 0,000 \\
2 & Kesejahteraan & 0,500 & 0,936 \\
\hline Sumber:Data diolah, 2019 &
\end{tabular}

Pembangunan Bali Timur. Wilayah ini meliputi Kabupaten Karangasem, Kabupaten Klungkung, dan Kabupaten Bangli. Lokasi ini dipilih karena pada wilayah pembangunan Bali Timur masih terdapat kesenjangan antar sektor, antar wilayah dan pendapatan perkapita serta pada wilayah pembangunan Bali Timur kondisinya relative tertinggal dibandingkan dengan wilayah Bali Selatan.

Populasi dalam penelitian ini adalah seluruh rumah tangga miskin di Wilayah Pembangunan Bali Timur, meliputi Kabupaten Klungkung, Karangasem dan Kabupaten Bangli. Metode Penentuan Sampel penelitian ini menggunakan teknik sampling kuota. Dalam menentukan anggota sampel, penelitian ini mengambil 81 sampel di Wilayah Pembangunan Bali Timur maka penarikan sampel per Kabupaten di Wilayah Pembangunan Bali Timur adalah masingmasing 27 sampel, karena 27 merupakan sampel besar minimal. Teknik analisis data yang digunakan dalam penelitian ini adalah metode analisis jalur(Path Analysis). Persamaan model struktural sebagai berikut.

Persamaan sub struktural I :

$$
\mathrm{Y} 1=\beta 1 \mathrm{X} 1+\beta 2 \mathrm{X} 2+\beta 3 \mathrm{X} 3+\mathrm{e} 1
$$

Persamaan sub struktural II :

$\mathrm{Y} 2=\beta 4 \mathrm{X} 1+\beta 5 \mathrm{X} 2+\beta 6 \mathrm{X} 3+\beta 7 \mathrm{Y} 1+\mathrm{e} 2 \ldots .(2)$

\section{HASIL DAN PEMBAHASAN}

Syarat minimum yang dianggap dapat memenuhi syarat uji validitas instrument penelitian adalah jika $r=0,30$ dan signifikansi $<0,05$. Jadi jika korelasi antara butir skor dengan skor total kurang dari 0,30 dan signifikansi $>0,05$ maka butir pernyataan dalam instrument tersebut dinyatakan tidak valid. Hasil uji validitas dapat dilihat pada Tabel 3 berikut.

Berdasarkan hasil uji validitas pada Tabel 3, dapat diketahui bahwa nilai seluruh indikator pernyataan dalam variabel penelitian ini lebih besar dari 0,30 dan signifikansi $<0,05$ sehingga dapat disimpulkan bahwa seluruh indikator tersebut adalah valid atau memenuhi syarat dan dapat dipakai untuk melakukan pengumpulan data penelitian.

Kaiser Meyer Olkin digunakan untuk mengetahui validitas konstruk dari analisis faktor. Analisis faktor dianggap layak jika besaran KMO memiliki nilai minimal 0,5. Hasil uji KMO dapat dilihat pada Tabel 4.

Hasil uji yang ditunjukan dalam Tabel 4 menunjukkan bahwa nilai Kaiser Meyer Olkin (KMO) variabel ketersediaan infrastruktur lebih besar dari 0,5 dan nilai signifikansinya lebih kecil dari 5 persen $(0,05)$, maka ini berarti variabel kesejahteraan memiliki 
Tabel 5.

Nilai MSA

\begin{tabular}{lll}
\hline Variabel & Indikator & Nilai MSA \\
\hline \multirow{4}{*}{ Ketersediaan Infrastruktur } & X2.1 & 0,855 \\
& X2.2 & 0,886 \\
& X2.4 & 0,943 \\
Kesejahteraan & X2.5 & 0,897 \\
& Y2.1 & 0,876 \\
& Y2.2 & 0,500 \\
\hline
\end{tabular}

Tabel 6.

Hasil Analisis Jalur Regresi I

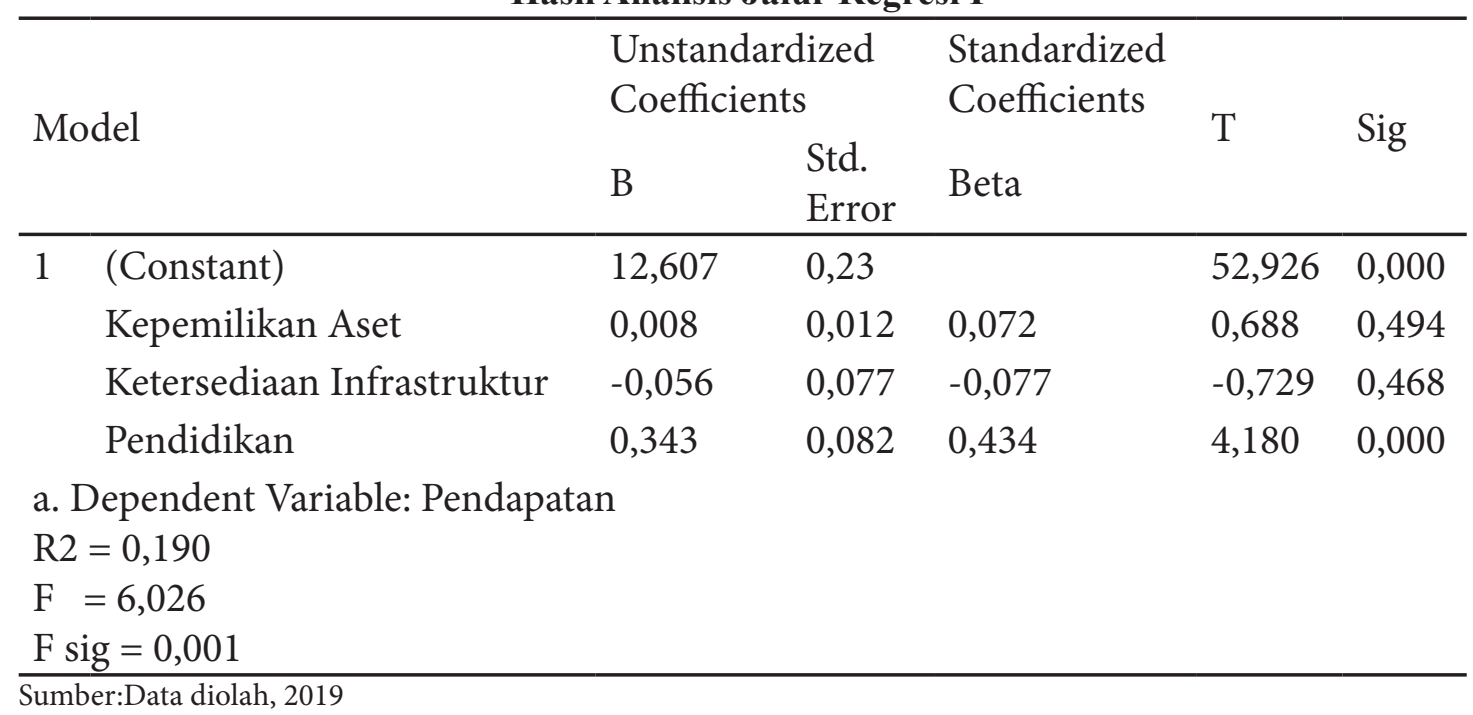

kecukupan sampel untuk melakukan analisis faktor.Kaiser Meyer Olkin (KMO) variabel kesejahteraan tidak lebih besar dari 0,5 dan nilai signifikansinya lebih besar dari 5 persen $(0,05)$, maka ini berarti variabel kesejahteraan tidak memiliki kecukupan sampel untuk melakukanan alisis faktor. Kelayakan model uji faktor untuk masing-masing variabel dapat dilihat dari nilai Measures of Sampling Adequancy (MSA). Model yang dipakai dikatakan layak digunakan apabila nilai MSA masing-masing variabel lebih besar dari 0,5. Nilai MSA yang diperoleh dari masing-masing variabel dapat dilihat pada Tabel 5.

Tabel 5 menunjukan hasil uji MSA dari ketersediaan infrastruktur dan kesejahteraan. Ketersediaan infrastruktur terdiri atas 5 indikator. Dimana dari indikator untuk variabel kesejahteraan pekerja tersebut menunjukan nilai MSA masing-masing indikator variabel lebih besar dari 0,5 yang berarti masingmasing model layak digunakan dalam analisis. Indikator yang memiliki nilai MSA tertinggi adalah X2.3 sebesar 0,943. Hasil uji MSA dari kesejahteraan yang terdiriatas 2 indikator, dimana dari indikator untuk kesejahteraan menunjukan nilai MSA masing-masing indikator sebesar 0,500 .

Pengujian data dalam penelitian ini menggunakan teknik analisis jalur (Path Analysis). Metode ini merupakan perluasan dari metode regresi liniar berganda untuk menguji hubungan kausalitas antar dua atau lebih variabel. Ada pun tahapan dalam pengujian dengan teknik analisis ini yaitu sebagai berikut: Pengujian persamaan satu dilakukan untuk melihat pengaruh kepemilikan aset, ketersediaan infrastruktur, dan pendidikan terhadap pendapatan, hasil uji regresi disajikan dalam Tabel 6. 
Tabel 6.

Hasil Analisis Jalur Regresi I

\begin{tabular}{|c|c|c|c|c|c|c|}
\hline \multirow{2}{*}{\multicolumn{2}{|c|}{ Model }} & \multicolumn{2}{|c|}{$\begin{array}{l}\text { Unstandardized } \\
\text { Coefficients }\end{array}$} & \multirow{2}{*}{$\begin{array}{l}\text { Standardized } \\
\text { Coefficients } \\
\text { Beta }\end{array}$} & \multirow{2}{*}{$\mathrm{T}$} & \multirow{2}{*}{ Sig } \\
\hline & & B & $\begin{array}{l}\text { Std. } \\
\text { Error }\end{array}$ & & & \\
\hline \multirow[t]{5}{*}{1} & (Constant) & 1,129 & 1,173 & & ,963 & ,338 \\
\hline & Kepemilikan Aset & $-0,286$ & 011 &,- 256 & $-2,485$ &, 015 \\
\hline & Ketersediaan Infrastruktur &, 031 & 071 & 045 & ,437 & ,663 \\
\hline & Pendidikan & ,164 & ,076 & 224 & 2,145 & 035 \\
\hline & Pendapatan &, 157 & 089 & ,182 & 1,750 & 0,84 \\
\hline & $\begin{array}{l}\text { ependent Variable: Kesejaht } \\
=0,065 \\
=1,313 \\
g=0,273 \mathrm{~b}\end{array}$ & aan & & & & \\
\hline
\end{tabular}

Berdasarkan hasil Tabel 6 maka persamaan sub-struktural 1 adalah sebagai berikut.

$$
\hat{\mathrm{Y}} 1=0,72 \mathrm{X} 1+-, 077 \mathrm{X} 2+434 \mathrm{X} 3
$$

$\mathrm{e} 1=\sqrt{1-\mathrm{R}_{1}^{2}}$

$=\sqrt{1-0,0} 65$

$=\sqrt{0,935}$

$=0,966$

Pengujian persamaan dua dilakukan untuk melihat pengaruh kepemilikan aset, ketersediaan infrastruktur, pendidikan dan pendapatan terhadap kesejahteraan, hasil uji regresi disajikan dalam Tabel 7.

Berdasarkan hasil Tabel 7 maka persamaan sub-struktural 2 adalah sebagai berikut:

$$
\begin{aligned}
\hat{\mathrm{Y}} 2= & -0,102 \mathrm{X} 1+0,43 \mathrm{X} 2+0,150 \mathrm{X} 3+ \\
& 0,117 \mathrm{Y} 1+\mathrm{e} 2
\end{aligned}
$$

Untuk mengetahui nilai e1 yang menunjukan jumlah variance variabel pendapatan pekerja yang tidak dijelaskan oleh kepemilikan aset, ketersediaan infrasrtuktur dan pendidikan dapat dihitung dengan menggunakan rumus :

$$
\begin{aligned}
\mathrm{e}_{1} & =\sqrt{1-\mathrm{R}_{1}^{2}} \\
& =\sqrt{1-0,190} \\
& =\sqrt{0,810} \\
& =0,9
\end{aligned}
$$

Sedangkan untuk mengetahui nilai e2 yang menunjukan variance variabel kesejahteraan rumah tangga miskin yang tidak dijelaskan oleh variabel jam kepemilikan aset, ketersediaan infrastruktur, pendidikan dan pendapatan maka dapat dihitung dengan menggunakan rumus :

Untuk memeriksa validitas model, terdapat indikator untuk melakukan pemeriksaan, yaitu koefisien determinasi total hasilnya sebagai berikut :

$$
\begin{aligned}
\mathrm{R}_{\mathrm{m}}^{2} & =1-(\mathrm{e} 1)^{2}(\mathrm{e} 2)^{2} \\
& =1-(0,9)^{2}(0,966)^{2} \\
& =1-0,756 \\
& =0,244
\end{aligned}
$$

Keterangan:

$\mathrm{R}_{\mathrm{m}}^{2} \quad$ : Koefisien determinasi total.

$\mathrm{e}_{1}, \mathrm{e}_{2}$ : Nilai kekeliruan taksiran standar.

Berdasarkan hasil perhitungan

koefisien determinasi total, maka diperoleh bahwa keragaman data yang dapat dijelaskan oleh model adalah sebesar 0,244 atau dengan kata lain informasi yang terkandung dalam data sebesar 24,4 persen dapat dijelaskan oleh model, sedangkan sisanya yaitu75,6 persen dijelaskan oleh variabel lain yang tidak terdapat dalam model.

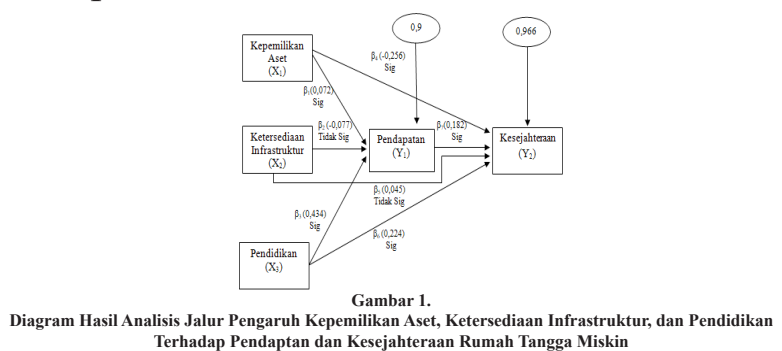


Nilai signifikansi $0,494<0,10$ maka kesimpulannya adalah $\mathrm{H} 0$ diterima dan H1ditolak, ini berarti kepemilikan aset tidak berpengaruh positif atau tidak berpengaruh terhadap pendapatan rumah tangga miskin di Wilayah Pembangunan Bali Timur. Hasil penelitian ini sesuai dengan penelitian yang dilakukan oleh Andi Nugroho (2010) bahwa kepemilikan aset memiliki pengaruh positif terhadap pendapatan rumah tangga miskin. Hal ini disebabkan ketika kepemilikan aset meningkat, pada saat itu kebutuhan hidup meningkat juga. Nilai signifikansi $0,468<$ 0,10 maka kesimpulannya adalah H0 diterima dan H1ditolak, ini berarti ketersediaan infrastruktur tidak berpengaruh positif atau tidak berpengaruh terhadap pendapatan rumah tangga miskin di Wilayah Pembangunan Bali Timur. Menurut hasil penelitian sebelumnya yang dilakukan oleh Muhammad Amin (2014) ketersediaan infrastruktur tidak selalu berpengaruh positif terhadap pendapatan. Contohnya pada kelompok masyarakat yang memiliki mata pendaharian utama sebagai buruh tani perkebunan dan buruh angkut, naikknya produksi lahan ternyata tidak berpengaruh terhadap jumlah pendapatan mereka

Nilai signifikansi $0,000<0,10$ maka kesimpulannya adalah $\mathrm{H} 0$ ditolak dan H1 diterima, ini berarti pendidikan berpengaruh positif atau tidak berpengaruh terhadap pendapatan rumah tangga miskin di Wilayah Pembangunan Bali Timur. Menurut Hermanto Siregar dan Dwi Wahyuniarti (2008), didalam penelitiannya bahwa pendidikan yang diukur denganjumlahpenduduk yanglulus pendidikan SMP, SMA, dan Diploma berpengaruh dan signifikan terhadap penurunan jumlah penduduk miskin. Ini mencerminkan bahwa pembangunan modal manusia (human capital) melalui pendidikan merupakan determinan penting untuk menurunkan jumlah penduduk miskin.

Nilai signifikansi $0,015>0,10$ maka kesimpulannya adalah $\mathrm{H} 0$ diterima dan H1ditolak .Artinya kepemilikan aset tidak berpengaruh terhadap kesejahteraan rumah tangga miskin di Wilayah Pembangunan Bali
Timur. Menurut Hermanto Siregar dan Dwi Wahyuniarti (2008), didalam penelitiannya bahwa pendidikan yang diukur dengan jumlah penduduk yang lulus pendidikan SMP, SMA, dan Diploma berpengaruh dan signifikan terhadap penurunan jumlah penduduk miskin. Ini mencerminkan bahwa pembangunan modal manusia (human capital) melalui pendidikan merupakan determinan penting untuk menurunkan jumlah penduduk miskin.

Nilai signifikansi $0,663>0,10$ maka kesimpulannya adalah H0 diterima dan H1 ditolak, ini berarti ketersediaan infrastruktur tidakberpengaruhpositifatautidakberpengaruh terhadap kesejahteraan rumah tangga miskin di Wilayah Pembangunan Bali Timur. Hasil penelitian ini sesuai dengan hasil penelitian yang dilakukan oleh Meiyora Averina (2013), bahwa ketersediaan infrastruktur berpengaruh positif terhadap kesejahteraan masyarakat. Tersedianya infrastruktur dengan kondisi yang baik memberikan keunggulan untuk bersaing secara kompetitif dalam memasarkan hasil produknya, mempermudah mobilitas penduduk, mengembangkan industri serta meningkatkan pendapatan yang berpengaruh secara langsung terhadap kesejahteraan masyarakat.

Nilai signifikansi0,035 $>0,10$ maka kesimpulannya adalah H0 diterima dan H1ditolak. Artinya pendidikan berpengaruh positif terhadap kesejahteraan rumah tangga miskin di Wilayah Pembangunan Bali Timur. Hasil penelitian ini sesuai dengan hasil penelitian yang dilakukan oleh Ella Nur Aini dkk (2018) bahwa tingkat pendidikan memiliki hubungan yang positif dan signifikan terhadap kesejahteraan masyarakat. Suatu masyarakat dengan tingkat pendidikan tinggi diharapkan juga memiliki kualitas hidup yang tinggi sehingga kesejahteraan dapat tercapai.

Nilai signifikansi $0,084<0,10$ maka kesimpulannya adalah $\mathrm{H} 0$ diterima dan $\mathrm{H} 1$ ditolak, ini berarti pendapatan berpengaruh positif dan siginifikan terhadap kesejahteraan rumah tangga miskin di Wilayah Pembangunan Bali Timur. Hasil penelitian ini sesuai dengan hasil penelitian yang dilakukan oleh Nanda Herawan (2014), bahwa pendapatan 
berpengaruh positif dan signifikan terhadap pendapatan. Setiap manusia mempunyai pendapatan yang berbeda-beda. Pendapatan itulah yang digunakan sebagai alat pemenuh kebutuhan. Semakin banyak pendapatan yang diperoleh, semakin banyak juga terpenuhinya kebutuhan yang diinginkan. Terpenuhinya kebutuhan yang diinginkan oleh seseorang membuat dirinya semakin dekat untuk mencapai kesejahteraan.

\section{SIMPULAN}

Kepemilikan aset berpengaruh
positif tetapi tidak signifikan terhadap pendapatan. Ketersediaan infrastruktur tidak berpengaruh terhadap pendapatan. Pendidikan berpengaruh positif dan signifikan terhadap pendapatan rumah tangga miskin di Wilayah Pembangunan Bali Timur. Kepemilikan aset tidak berpengaruh terhadap kesejahteraan. Ketersediaan infrastruktur berpengaruh positif terhadap kesejahteraan. Pendidikan dan pendapatan berpengaruh positif dan signifikan terhadap kesejahteraan. Kepemilikan aset, ketersediaan infrastruktur, dan pendidikan tidak berpengaruh secara tidak langsung terhadap kesejahteraan melalui pendapatan.

Perlunya kesadaran dari seluruh lapisan masyarakat terhadap pengentasan kemiskinan. Mulai dari pemerintah atau pejabat (pusat dan daerah) sampai rumah tangga miskin itu sendiri. Perlunya peningkatan kualitas sumber daya manusia, misalnya dengan lebih mengutamakan bantuan terhadap sektor Pendidikan. Kepala rumah tangga yang bekerja sebaiknya dapat membentuk kelompok usaha. Kelompok usaha ini disesuaikan dengan pekerjaan serta kemampuan dalam menghasilkan produktivitas yang dimiliki oleh masing-masing kepala rumah tangga untuk meningkatkan pendapatannya. Pendapatan akan bertambah jika kepala rumah tangga mampu bekerja secara produktif dengan memanfaatkan waktu luang sebaik-baiknya dan meningkatkan pengetahuan dengan mencapai pendidikan yang tingkatannya lebih tinggi.

Perlunya program khusus bagi masyarakatmiskindalamrangkameningkatkan kesadaran masyarakat tentang pentingnya pendidikan dan ketrampilan bagi manusia sehingga rumahtangga miskin yang memiliki aset dapat menciptakan lapangan pekerjaan sendiri dan memanfaatkan infrastruktur yang telah disediakan oleh Pemerintah guna meningkatkan pendapatan sehingga dapat menciptakan kualitas hidup yang lebih baik lagi. Bagi peneliti selanjutnya diharapkan dapat menjadi referensi dan disarankan untuk menambah variabel lain dan bervariasi sehingga dapat melengkapi kajian mengenai kemiskinan agar dapat diketahui faktor apa saja yang dapat mempengaruhinya.

\section{REFERENSI}

Abdul Kadir, Azwardi, Susi Wardhani R, Novalia Nurkadina, Maulana Ahmad. 2018. The Impact of Physical and Human capital on the Economic Growth of Agricultural Sector in South Sumatera. 8(4) pp : 322-326

Abebe Thesome, Quaicoe Nana. 2014. Causes of Poverty in Sub-Saharan Africa: A Layered Theory Approach to Understanding Significant Factors. 6(6) pp : 112-124

Alcock, Pete. 2012. Poverty and Social Exclusion. The Student's Companion to Social Policy. Fourth Edition, pp: 26-186.

Andi Nugroho. 2010. Faktor-Faktor Penyebab Meningkatnya Rumah Tangga Miskin di Kecamatan Suruh Kabupaten Semarang. Jurnal Universitas Negeri Semarang.

Anne Booth. 2000. Poverty and Inequality in The Soeharto Era : An Assessment. Bulletin Of Indonesian Economic Studies. 36 (1) pp : 73-104.

Alit, Wiradyatmika A.A Gde dan Sudiana. 2013. Pengaruh Jumlah Penduduk, Jumlah Penyerapan Tenaga Kerja dan Pengangguran Terhadap Jumlah 
Penduduk Miskin di Kabupaten Buleleng. Jurnal Ekonomi Pembangunan, Fakultas Ekonomi dan Bisnis Universitas Udayana.

Badan Pusat Statistik Provinsi Bali. 2018. Data dan Informasi Kemiskinan Kabupaten/Kota. Bali: BPS Provinsi Bali.

Balisacan, Arsenio M. 2003. Revesiting Growth And Poverty Reduction In Indonesia: What Do Subnational Data Show?. Jurnal Bulletin of Indonesian Economic Studies University of the Philippines-Diliman and SEAMEO Regional Center for Graduate Study and Research in Agriculture. 39(3). 330-350.

Bourbuignon Francois, Cakravarty Satya R. 2003. The Measurment of Multidimensional Poverty. 1(1) pp : 25-49

Bryant, W.K. 1990. Understanding Information System, Foundations for Control. Pretince-Hall of India, New Delhi.

Capra, Theresa. 2009. Poverty and its Impact on Education:Today and Tomorrow. pp : 75-81

Fatimah, Empat. 1995. Beberapa Faktor yang Mempengaruhi Alokasi Pengeluaran dan Tingkat Konsumsi Pangan Keluarga (Studi Kasus di Kelurahan Tanah Sareal, Bogor). Institut Pertanian Bogor. Bogor

Hukom, Alexandra. 2014. Hubungan Ketenagakerjaan Dan Perubahan Struktur Ekonomi terhadap Kesejahteraan Masyarakat. Jurnal Ekonomi Kuantitatif Terapan Jurusan Ilmu Ekonomi dan Studi Pembangunan Fakultas Ekonomi Universitas Palangka Raya. 7 (2). 120-129.
Iskandar, Hartoyo, Sumarwan Ujang, Khomsan Ali. 2007. Faktor-Faktor yang Mempengaruhi Kesejateraan Keluarga. Universitas Sumatera Utara. 133-141

Kembar Sri Budhi, 2013. Analisis FaktorFaktor yang Berpengaruh Terdahap Pengentasan Kemiskinan di Bali: Analisis FEM Data Panel. Jurnal Ekonomi Kuantitatif Terapan. 6(1) hal : 1-6

Nasir, M. Muh, Saichudin dan Maulizar. 2008. Analisis Faktor-Faktor yang Mempengaruhi Kemiskinan Rumah Tangga Di Kabupaten Purworejo. Jurnal Eksekutif. Vol. 5 No. 4, Agustus 2008. Jakarta : Lipi

Pratomo Shasta Devanto. 2017. Pendidikan dan Partisipasi Angkatan Kerja Wanita di Indonesia: Analisis Terhadap Hipotesis Kurva-U. Jurnal Ekonomi Kuantitatif Terapan. 10(1) hal: 1-7

Purwanto Agung, Taftazani Muhammad. 2018. Pengaruh Jumlah Tanggungan Terhadap Tingkat Kesejahteraan Ekonomi Keluarga Pekerja K3L Universitas Padjajaran. Jurnal Ekonomi Kuantitatif Terapan. 1(2) hal: $33-43$

Putrayasa I Made, Purbadharmaja Ida Bagus Putu. 2019. The Influence of Socialization and Economic Potential on Productivity and Income of Village Owned Entreprises in Seririt District. Jurnal of Humanites and Social Science. Vol 24

Putri, Arya Dwinanda dan Setiawina Nyoman Djinar. 2013. Pengaruh Umur, Pendidikan, Pekerjaan Terhadap Pendapatan Rumah Tangga Miskin di Desa Bebandem. E-Jurnal Ekonomi Pembangunan Universitas 
Udayana. 2 (2).

Radhakrishna, R at all. 2007. Estimation and Determination of Chronic Poverty In India: An Alternative Approach. Chronic Poverty Journal.

Sinaga dan Nyak Ilham. 2002. Penggunaan Pangsa Pengeluaran Pangan Sebagai Indikator Komposit Ketahanan Pangan. Pusat Analisis Sosial Ekonomi dan Kebijakan Pertanian. Bogor.

Soekirman. 2000. Ilmu Gizi dan Aplikasinya. Jakarta: Direktorat Jenderal Pendidikan Tinggi, Departemen Pendidikan Nasional.

Suryahadi Asep, Hadiwidjaja Gracia, Sumarto Sudarno. Economic Growth and Poverty Reduction in Indonesia Before and After the Asian Financial Crisis. Bulletin Of Indonesian Economic Studies. pp : 13.

Tisnawati Made. 2016. Partisipasi Kelas Menengah Dalam Pengentasan Kemiskinan Perdesaan di Kabupaten Gianyar. PIRAMIDA. 12(2) hal:72-79
Verner, Dorte. 2006. Rural Poor in Rich Rural Areas: Poverty in Rural Argentina. $\mathrm{pp}: 3$.

Vincent, Brian. 2009. The Concept 'Poverty' towards Understanding in the Context of Develoving Countries 'Poverty qua Poverty'. Journal of Sustainable Development. 2 (2).

Yanthi Dian Purnama, Marhaeni. 2015. Pengaruh Pendidikan, Tingkat Upah dan Pengangguran Terhadap Persentase Penduduk Miskin di Kabupaten/Kota Provinsi Bali. PIRAMIDA. 9(2) hal : 68-75.

Yasa Artana Oka, Arka Sudarsana. 2015. Pengaruh Pertumbuhan Ekonomi dan Disparitas Pendapatan Antar daerah Terhadap Kesejahteraan Masyarakat Provinsi Bali. Jurnal Ekonomi Kuantitatif Terapan. 8(1) hal : 63-71

Yusuf dan Sumner. 2015. Growth, Poverty, and Inequality Under Jokowi. Bulletin Of Indonesian Economic Studies, Vol.51, No.3, ISSN:0007-4918. 